\title{
The Massachusetts Health Plan: The Good, the Bad, and the Ugly
}

\author{
David A. Hyman*
}

I. INTRODUCTION plan.",

" It is not a typical Massachusetts-Taxachusetts, oh-just-crazy-liberal

Those of us who live in fly-over country know what to expect from Massachusetts. The state is notorious for its left-wing politicians, its wacky social policies, and its "yellow-dog Democrat" voting record in presidential elections. ${ }^{2}$ It is "viewed by the rest of America as a sort of Marxist redoubt with great seafood.", Even its own residents call it "Taxachusetts." We've seen the Massachusetts miracle, and we know how the movie ends. ${ }^{5}$

\footnotetext{
- Professor of Law and Medicine, University of lllinois. A modified version of this article was published by the Cato Institute as a Policy Analysis bearing the same title. See David A. Hyman, The Massachusetts Health Plan: The Good, The Bad, and the Ugly, Cato Institute Policy Analysis no. 595 (2007), available at http://www.cato.org/pub_display.php?pub_id=8431.

1. Pam Belluck, Massachusetts Sets Health Plan for Nearly All, N.Y. TiMES, Apr. 5, 2006, at Al (quoting Stuart H. Altman, professor of health policy at Brandeis University).

2. A yellow dog Democrat is someone who would vote for a little yellow dog if it was running on the Democratic ticket. Cf. IRVIN S. COBB, EXIT LAUGHING 208 (1941) ("'I admit,' he stated blandly, 'that I said then what I now repeat, namely, that when the Democratic party of Kentucky, in convention assembled, sees fit in its wisdom to nominate a yaller dog for the governorship of this great state, I will support him ...."). Massachusetts was the only state in the union in which George McGovern got more votes than Richard Nixon in the 1972 presidential election. Enough said. National Journal, Massachusetts: State Profile, http://election.nationaljournal.com/states/ma.htm (last visited Mar. 9, 2007).

3. Noel C. Paul, Massachusetts Conservatives, THE NEW REPUBLIC ONLINE, July 20, 2004, http://www.tnr.com/doc.mhtml?i=express\&s=paul072004.

4. See Belluck, supra note 1 .

5. See P.J. O'RourKe, PARLIAMENT OF WhORES 28 (1991) (“Michael Dukakis's pitch to the voters was that Massachusetts (a state where he was governor when he had a moment) possessed a swell economy. Never mind that the Massachusetts high-tech boom was about to collapse like a Red Sox pennant race. And never mind that the boom, when it did exist, was the result of hog-wild defense spending and hard work, two things Democrats are not known for promoting. Furthermore, never mind that the small, homely state of Massachusetts had an awful deficit, nasty drug and race problems, no housing at any price and the filthiest harbor and worst traffic jams this side of Lagos, Nigeria.").
} 
That said, the Massachusetts health plan is not, as Professor Stuart Altman neatly put it, "a typical Massachusetts-Taxachusetts, oh-justcrazy-liberal plan." Instead, the plan represents a hybrid approach, incorporating ideas from across the political spectrum. ${ }^{7}$ The plan was promoted by a moderately conservative Republican governor with national political aspirations, and enacted by a liberal Democratic House and Senate. The plan is boosted by the Heritage Foundation on the right, ${ }^{8}$ and Families USA on the left. ${ }^{9}$ To be sure, the plan has detractors across the political spectrum as well. ${ }^{10}$

\section{Belluck, supra note 1}

7. See Marilyn Werber Serafini, The Mass.-ter Plan, NAT'L J., June 10, 2006, at 22, 23 ("TThe] plan ... brings together ideas ... from both the liberal and conservative camps...."). A summary of the plan can be found online. HEALTH CARE ACCESS AND AFFORDABILITY, CONFERENCE COMMITTEE REPORT, S. 184-2282, at 1-5 (Mass. 2006), available at http://www. mass.gov/legis/summary.pdf [hereinafter CONFERENCE COMMITTEE REPORT]

Other useful sources on the plan and its details include a series of web articles in Health Affairs. See generally John Holahan \& Linda Blumberg, Massachusetts Health Care Reform: A Look at the Issues, 2006 HEALTH AFF.: WEB EXCLUSIVES w432 (analyzing four major issues the Massachusetts plan will face); John E. McDonough et al., The Third Wave of Massachusetts Health Care Access Reform, 2006 HEALTH AFF.: WEB EXCluSIVES w420 (describing the new statute and the process leading to its passage); Elizabeth A. McGlynn \& Jeffrey Wasserman, Massachusetts Health Reform: Beauty is in the Eye of the Beholder, 2006 HEALTH AFF.: WEB EXCLUSIVES w447 (describing the political and analytical lessons learned and how they might apply elsewhere); Tom Miller, Massachusetts: More Mirage than Miracle, 2006 HEALTH AFF.: WEB EXCLUSIVES w450 (arguing reforms are "too little and too late" to succeed); Nancy C. Turnbull, The Massachusetts Model: An Artful Balance, 2006 HEALTH AFF.: WEB EXCLUSIVES w453 (discussing challenges the plan will face).

Finally, National Journal's Policy Council held a panel discussion on health care reform in Massachusetts, keynoted by Governor Mitt Romney, on September 21, 2006. Transcript of Health Care Reform: The Massachusetts Model, available at http://policycouncil.nationaljournal.com/ EN/ForumBriefs/200610/ed17dec0-a64d-42c7-8317-4c62afl357cc.htm (last visited Mar. 9, 2007).

8. See Edmund F. Haislmaier, The Significance of Massachusetts Health Reform, Web Memo No. 1035, THE HERITAGE FOUND., http://www.heritage.org/Research/HealthCare/wm1035.cfm (discussing pros and cons of plan features); Robert E. Moffit \& Nina Owcharenko, Understanding Key Parts of the Massachusetts Health Plan, Web Memo No. 1045, The HeRITAGe Found., http:// www.heritage.org/Research/HealthCare/wm1045.cfm (same).

9. See Press Release, Families USA, Massachusetts Legislature Passes Landmark Health Coverage Expansion (Apr. 4, 2006), available at http://www.familiesusa.org/resources/ newsroom/statements/2006-statements/massachusetts-legislature.html (calling the plan "laudable" and finding a "net benefit" to business).

10. See J.P. WIESKE, COUNCIL For AfFordable Health INS., MASSACHUSETtS' HEalth CARE REFORM PLAN: TOO MANY STICKS; NOT ENOUGH CARROTS (2006), available at http://www. cahi.org/cahi_contents/resources/pdf/massachusetts.pdf (" $T$ T]here is little hope that the new legislation will make health insurance more affordable."); Michael Tanner, No Miracle in Massachusetts: Why Governor Romney's Health Care Reform Won't Work, CATO Institute Briefing Papers No. 97, June 6, 2006, at 2, available at http://www.cato.org/pub_display.php?pub_id=6407 (describing the Massachusetts plan as "one of the most far-reaching experiments in health care reform since Bill Clinton's ill-fated attempt at national health care"); Amold Kling, Bill of Health, Wall ST. J., Apr. 7, 2006, at A12 ("The elected leaders of Massachusetts have come up with a novel solution for the vexing problem of paying for health care: abolish the laws of arithmetic."); Sally C. Pipes, Massachusetts Will Fail, USA TODAY, Apr. 9, 2006, at A13 ("Massachusetts' health 
It is illuminating to view the Massachusetts health plan through a theatric/cinematic lens. " When I presented a paper at the University of Kansas Law Review Symposium in Lawrence on November 10, 2006, I organized my remarks around whether the Massachusetts health plan was more like Brigadoon or Camelot. Further reflection has persuaded me that it is more useful to analyze the Massachusetts health plan in light of The Good, the Bad, and the Ugly, a classic Sergio Leone movie starring Clint Eastwood, Eli Wallach, and Lee Van Cleef.

Part II of this Article outlines the basic details of the Massachusetts health plan. Part III details "the good" of the plan. Part IV details "the bad" of the plan. Part V lays out "the ugly" of the plan. Part VI concludes.

\section{WhAT'S IT ALL ABOUT?}

Depending on the source, between $7.2 \%$ and $10.7 \%$ of the Massachusetts population lacks health insurance. ${ }^{12}$ To address this problem, the Massachusetts health plan incorporates an array of elements. The key components are as follows: (1) an individual mandate; (2) an employer mandate (play or pay), and a requirement that employers create a Section 125 cafeteria plan; (3) a Connector through which uninsured residents can purchase health insurance; and (4) subsidies for those with incomes up to 3 times the federal poverty level. Each of these provisions is briefly described. ${ }^{13}$ Those wishing more

care plan won't lead to universal care through private insurance.").

At the other end of the political spectrum, see Steffie Woolhandler \& David Himmelstein, Massachusetts Health Reform Bill: A False Promise of Universal Coverage (2005), http://www .pnhp.org/news/2006/april/massachusetts_health.php ("The legislation offers empty promises and ignores real-and popular-solutions."). See also Serafini, supra note 7, at 24 ("On the left, the AFL-CIO predicts that many low-income people won't be able to afford good insurance, and will get skimpy plans.').

11. And not just because I always wanted to use the word "lens" in a law review article.

12. See Carmen denovas-Walt, Bernadette D. Proctor \& Cheryl hill Lee, U.S. Census Bureau, Income, Poverty and Health Insurance Coverage in the United States: 200527 (2006) (estimating that, on average, 10.7\% of the Massachusetts population was uninsured between 2003 and 2005); COMMONWEALTH HEALTH INSURANCE CONNECTOR AUTHORITY BOARD of Directors, AN ACT Providing aCcess to AFFordable, Quality, AND ACCOUNTABle HEALTH CARE: SUMMARY OF KEY FEATURES 1 (2006), available at http://www.mass.gov/ Qhic/docs/HCRnarrativefinal.doc ("In 2004, the Commonwealth's household insurance survey estimated that there were 460,000 people [7.2\%] in Massachusetts without health insurance ...."); CONFERENCE COMMITTEE REPORT, supra note 7, at 1 (estimating that 550,000 people, or $8.6 \%$ of the Massachusetts population, are uninsured).

13. CONFERENCE COMMITTEE REPORT, supra note 7, at 1-3. The Massachusetts health plan also includes other components. See id. at 1-5 (discussing other aspects of the Massachusetts plan, like insurance market reforms, fair share contributions, and Free Rider surcharge). 
detail can consult other sources, including the state's official website for the Connector. ${ }^{14}$

The individual mandate requires all Massachusetts residents who are eighteen or older to purchase health insurance. ${ }^{15}$ The sanction for not purchasing such insurance is levied through the state income tax. ${ }^{16}$ In 2007 , the penalty is the loss of the personal income tax exemptiontotaling roughly $\$ 220$ for an individual and $\$ 440$ for a family. ${ }^{17}$ In 2008 and thereafter, the penalty (imposed on those for whom coverage is "affordable") is set at half the monthly cost of the lowest-cost health insurance plan within a region for each month without coverage. ${ }^{18}$ The Connector Board is responsible for setting the definition of "affordable" and determining which policies meet coverage requirements. ${ }^{19}$

The play or pay component requires employers with eleven or more employees who do not make a "fair and reasonable" contribution to their employees' health insurance to pay an annual fee to the state. ${ }^{20}$ An employer makes a "fair and reasonable" contribution when it offers a group health plan and agrees to pay at least one-third of the cost of coverage under the plan, or it offers a group health plan in which at least $25 \%$ of full-time employees enroll and the employer makes a contribution. If these conditions are not satisfied, the employer must pay a fee-the "Fair Share Contribution"-currently capped at \$295 per employee, per year. ${ }^{21}$

Employers are also required to create a cafeteria plan to facilitate the ability of employees to purchase health insurance on a pre-tax basis. ${ }^{22}$ Under current law, an individual who obtains health insurance through his or her employer can do so with pre-tax dollars. Those who obtain coverage in other ways must do so with after-tax dollars-even if they

14. Official Website of the Commonwealth Connector, http://www.mass.gov/?pageID=hic homepage $\& \mathrm{~L}=1 \& \mathrm{~L} 0=$ Home\&sid=Qhic; see also CONFERENCE COMMITTEE REPORT, supra note 7, at 1-5 (containing "a comprehensive plan for increasing health insurance coverage for all residents of Massachusetts"); KAISER COMM'N ON MEDICAID \& THE UNINSURED, THE HENRY J. KAISER Family Found., Key Facts: Massachusetts Health CaRe Reform Plan 1-2 (Apr. 2006), available at http://www.kff.org/uninsured/upload/7494.pdf [hereinafter MASSACHUSETTS HEALTH CARE REFORM].

15. McDonough et al., supra note 7, at w424.

16. Id.

17. $I d$.

18. Id.

19. Id.

20. MASS. GEN. LAWS ch. 149, $\$ 188(\mathrm{~b})$ (2007).

21. Id. ch. $149, \S 188(\mathrm{c})(10)$. This surcharge is expected to raise between $\$ 31.5$ and $\$ 45$ million in 2007. McDonough et al., supra note 7, at w425.

22. McDonough et al., supra note 7 , at w425. 
are unable to purchase coverage through their employer and even if they are unemployed. ${ }^{23}$ This peculiar structure is the source of considerable horizontal and vertical inequity. ${ }^{24}$ The Massachusetts plan attempts to level-up the playing field since participation in a cafeteria plan allows participants to receive qualified benefits (including health insurance) on a pre-tax basis. Employers that do not offer a cafeteria plan face a "Free Rider Surcharge" that is triggered if the state pays more than $\$ 50,000$ for care provided to employees in any given year. ${ }^{25}$

Health insurance may be purchased through a Connector, which is designed to replace and supplement the old individual and small group markets by creating a health insurance exchange. The merger of the individual and small group markets and a temporary moratorium on additional mandates means that some Massachusetts residents will be able to obtain coverage at lower prices than was previously the case. ${ }^{26}$ The existence of the Connector is also likely to broaden the range of choices available to many individuals, pool the associated risk, and increase the portability of health insurance coverage.

Individuals with incomes up to $300 \%$ of federal poverty level ("FPL") will receive sliding scale subsidies, and individuals with incomes less than $100 \%$ of FPL will not have to pay any premiums. In practice, this means that subsidies can be provided well up the income scale, as $300 \%$ of FPL for a family of four is $\$ 60,000$.

23. See David A. Hyman \& Mark Hall, Two Cheers for Employment-Based Health Insurance, 2 YALE J. HEALTH POL'Y L. \& ETHICS 23, 25-26 (2001) (discussing the benefits of employment-based health insurance and the current tax implications of such insurance); see also FEDERAL TRADE COMM'N \& DEP'T OF JUSTICE, IMPROVING HEALTH CARE: A DOSE OF COMPETITION, ch. 5, 5-6, 11 12 (2004) (discussing current tax treatment of health insurance and possible reforms); Paul Fronstin, The Tax Treatment of Health Insurance and Employment-Based Health Benefits, EBRI ISSUE BRIEF No. 294 6-7, 13 (June 2006), available at http://www.ebri.org/pdf/briefspdf/EBRI_IB_06-20061.pdf (discussing tax treatment of health insurance generally).

24. Hyman \& Hall, supra note 23 , at 40.

25. McDonough et al., supra note 7, at w425.

26. CONFERENCE COMMITTEE REPORT, supra note 7 , at 1 (projecting a $24 \%$ drop in non-group premium costs); see also Haislmaier, supra note 8, at 3 (noting that insurers can offer Health Savings Accounts (HSAs) and coinsurance to those purchasing coverage through the Connector). However, all the existing mandates were retained. Tanner, supra note 10 , at 5-6. Premiums for those already covered in the small group market are likely to increase by $2 \%$ to $8 \%$. McDonough et al., supra note 7 , at $\mathbf{w} 426$. 


\section{III. "THE GOOD"}

\section{A. The Return of the States}

The most important "good" of the Massachusetts plan is the reemergence of the states as significant policy-setting entities. After eight decades of treating the states as embarrassing impediments to the glorious sweep of federal power, the left has suddenly embraced federalism. To be sure, it has only done so because it has been unable to enact its preferred policies for the nation as a whole, and it is likely to drop the state-based approach like a hot potato if it can get its way on the federal level-but better late than never. Since many states have balanced budget requirements, and none can print money, it will be interesting to see how these state-based reform strategies are modified when the fiscal reality of their plans slaps reformers in the face. ${ }^{27}$ The states also have limited ability to externalize their costs, ${ }^{28}$ so reform plans will sink or swim based on their real-world internalized costs, and not the typical "low money down" budgetary projections that have resulted in Medicare Parts A through D. ${ }^{29}$ With any luck, the return of the states will mark the return of fiscal rectitude and small-state government. Of course, if you believe that one...

\section{B. Spreading the Tax Preference}

The tax subsidy for employment-based health insurance has provoked criticism from across the political spectrum-although there is considerable disagreement on the best way to fix the problem. ${ }^{30}$ In the

27. Cf. SCROOGED (Mirage Productions \& Paramount Pictures 1998) ("Sometimes you have to ... SLAP them in the face to get their attention.").

28. To be sure, Medicaid creates significant opportunities for mischief, since states can externalize at least fifty percent (and for some states, as much as eighty percent) of the associated costs. For example, California's plans for expanding coverage rely on taxpayers in the rest of the country to pay a majority of the costs because the reliance on Medicaid-provider taxes triggers matching payments from the federal fisc. Though the costs internalized by each state are far less than the actual costs, they are still enough to sink the more ambitious plans and to push states to adopt other states' successes and avoid other states' failures.

29. See DAvid A. HYMAN, MEdiCARE MEets MEPhistopheles 15-17 (2006) (discussing Medicare Parts A through D).

30. See David A. Hyman, Getting the Haves to Come Out Behind: Fixing the Distributive Injustices of American Health Care, 69 LAW \& CONTEMP. PROBS. 265, 274 (2006) (cataloging different strategies for fixing the tax subsidy). After years of languishing in political obscurity, fixing the tax subsidy has surfaced in the past few years as a policy initiative. See REPORT OF THE PRESIDENT'S ADVISORY PANEL ON FED. TAX REForm, Simple, FAIR, AND PRO-GROWTH: 
absence of a political constituency for eliminating the preference entirely, Massachusetts did a good thing by expanding the pool of people receiving the subsidy. ${ }^{31}$

\section{Shifting the Focus}

Past debates over the uninsured have emphasized the expansion of governmental programs and the funding of safety net institutions. Massachusetts did a good thing by focusing instead on making it easier for the uninsured to obtain their own private health insurance. Stated differently, Massachusetts is now "[s]ubsidizing [p]eople, [n]ot [p]roviders." 32 The combination of broadened use of pre-tax dollars for those currently without employment-based insurance and subsidies for those least able to afford coverage has the potential to expand coverage without creating and/or worsening the public choice problems associated with the expansion of governmental programs to address the same problem. Now, who's ready to move on to other sectors of the economy, such as public education?

PROPOSALS TO FIX AMERICA'S TAX SYSTEM 81 (2005), available at http://www.taxreformpanel. gov/final-report/TaxReform_Ch5.pdf (recommending that individuals be allowed to purchase health insurance with pre-tax dollars up to a specified amount). The latest State of the Union address included a proposal to fix the tax subsidy. See News Release, The White House, President Bush Delivers State of the Union Address (Jan. 23, 2007), available at http://www, whitehouse.gov/ news/releases/2007/01/20070123-2.html ("I propose a standard tax deduction for health insurance that will be like the standard tax deduction for dependents. Families with health insurance will pay no income on payroll tax-or payroll taxes on $\$ 15,000$ of their income. Single Americans with health insurance will pay no income or payroll taxes on $\$ 7,500$ of their income. With this reform, more than 100 million men, women, and children who are now covered by employer-provided insurance will benefit from lower tax bills. At the same time, this reform will level the playing field for those who do not get health insurance through their job. For Americans who now purchase health insurance on their own, this proposal would mean a substantial tax savings $-\$ 4,500$ for a family of four making $\$ 60,000$ a year. And for the millions of other Americans who have no health insurance at all, this deduction would help put a basic private health insurance plan within their reach. Changing the tax code is a vital and necessary step to making health care affordable for more Americans.")

31. See Clark C. Havighurst, Health Care Cholces 103 (1995) ("[C]apping the tax subsidy is a notion that only a policy wonk could love, a meritorious policy idea with no natural political constituency.").

32. Haislmaier, supra note 8. 


\section{IV. "THE BAD"}

\section{A. Play or Pay: Preempted or Just Counterproductive?}

The play or pay provision faces a significant legal risk of preemption. $^{33}$ States that want a play or pay provision without risk of ERISA preemption need to go to Congress and get an exemption. If that approach was good enough for Hawaii, ${ }^{34}$ it is good enough for the rest of the states. Otherwise, the states might be busily experimenting in their respective policy laboratories for nothing. ${ }^{35}$

Unsatisfied with this approach, pay-or-play advocates have sought to amend ERISA to give the U.S. Department of Labor the authority to waive ERISA preemption and thereby allow states to experiment with additional regulations. Advocates of this approach emphasize that they merely seek to force employers not currently providing insurance either to do so, or to pay for the costs purportedly imposed on the state Medicaid program if they do not. Yet in their more candid moments they will admit their broader goals include direct regulation of the terms of coverage offered by self-funded employers, and the imposition of premium taxes on the amounts spent by these employers to provide coverage to their employees. But for the firewall created by ERISA, "pay-or-play" would soon degenerate into "pay or pay."

Worse still, play or pay is based on the same theory as a minimum wage law. If employers are not paying enough in wages (paying for health care coverage for their employees), just force them to increase those wages (pay for coverage). Everyone will be made better off, and no one will be made worse off. "[W]e can vote ourselves rich!"36

Nice try. The predictable adaptive responses will include laying off (or not hiring) employees and shifting to part-time employees because the cost of the minimum compensation package of full-time employees (wages plus "play or pay") exceeds its value to the enterprise. Indeed, a play or pay mandate is likely to be much more harmful than an increase in the minimum wage, since the costs imposed on employers on the

33. See Retail Indus. Leaders Ass'n v. Fielder, 475 F.3d 180, 183, 190-97 (4th Cir. 2007) (holding that Maryland's Fair Share Health Care Fund Act is preempted by ERISA).

34. See 29 U.S.C. $\$ 1144($ b)(5)(A) (2000) (exempting the Hawaii Prepaid Health Care Act from certain ERISA requirements).

35. See New State Ice Co. v. Liebmann, 285 U.S. 262, 311 (1932) ("It is one of the happy incidents of the federal system that a single courageous State may, if its citizens choose, serve as a laboratory; and try novel social and economic experiments without risk to the rest of the country.").

36. O'ROURKE, supra note 5 , at 220. 
"play" side of the equation will be tied to the rate of health care inflation, instead of the rate of general inflation.

That said, the current Massachusetts play or pay structure isn't nearly as counterproductive as the one Massachusetts adopted in 1985. That version required employers with six or more employees to provide health insurance and pay $80 \%$ of the cost, or be taxed $\$ 1680$ per employeeroughly $\$ 2900$ in 2007 dollars. The cost of the play and pay options in the current statute is much lower-and the pay option may be cheap enough that employers will just take $\$ 5$ per week out of the raise they were otherwise going to give out, instead of relocating, firing their least productive employees, or switching to part-timers. At the same time, it seems unlikely that employers currently offering coverage will suddenly decide they prefer the "pay" option-no matter how cheap that option is. That is the good part of the bad news. The bad part of the bad news is that the "pay" option is so cheap, it is unlikely to induce employers that do not offer coverage to start doing so.

Finally, there is little evidence that play or pay will get us to universal coverage. Consider Hawaii, the only state with such a mandate. Almost thirty years after the mandate was enacted, $10 \%$ of Hawaiians are uninsured ${ }^{37}$-a percentage that is either higher than or comparable to Massachusetts. The fact that Hawaii, with several thousand miles of ocean separating it from the nearest alternative location, could not get to universal coverage using an employer mandate suggests that play or pay is not going to solve Massachusetts' problem.

\section{B. Will an Individual Mandate Work?}

We want everyone to be insured, but not everyone is insured. An individual mandate certainly sounds like the most direct route between these two points. Unfortunately, the sanctions for noncompliance are far too low to encourage the purchase of coverage, even if one ignores the difficulties with enforcement. ${ }^{38}$ The sanctions only apply to individuals who file tax returns, and even for those individuals, the sanction is far below the cost of obtaining health coverage. ${ }^{39}$ The most optimistic estimate for the cost of coverage through the Connector is $\$ 200$ per

37. Belluck, supra note 1.

38. For more on the predictable difficulties with enforcing the Massachusetts plan, see Tanner, supra note 10 , at $4-5$.

39. See $i d$. at 5 (stating that the program has the "perverse effect of creating penalties that are large enough to be onerous but still smaller than the cost of purchasing insurance"). 
month ${ }^{40}$ - meaning that the plan is threatening taxpayers with a fine of $\$ 200$ (first year) or $\$ 1200$ (subsequent years) if they fail to incur a cost of $\$ 2400 .^{41}$ Any bets on the likelihood of this set of payouts increasing the level of coverage in Massachusetts?

Even if the sanction is considerably higher, it is hard to believe an individual mandate will materially increase coverage. Consider automobile liability insurance, where virtually all states impose an individual mandate and back it up with stiff sanctions (e.g., suspension of license, significant fines, and jail time). Automobile insurance is also cheaper than health insurance. ${ }^{42}$ Yet, $14.4 \%$ of motorists in the United States (6\% in Massachusetts) are uninsured. ${ }^{43}$ As Figure 1 illustrates, the state-by-state patterns for those without auto insurance ${ }^{44}$ bear an uncomfortable similarity to the patterns for those without health insurance. Indeed, the lack of insurance is so common that many drivers voluntarily buy coverage against a collision with an uninsured motorist, and more than a dozen states require such coverage. ${ }^{45}$

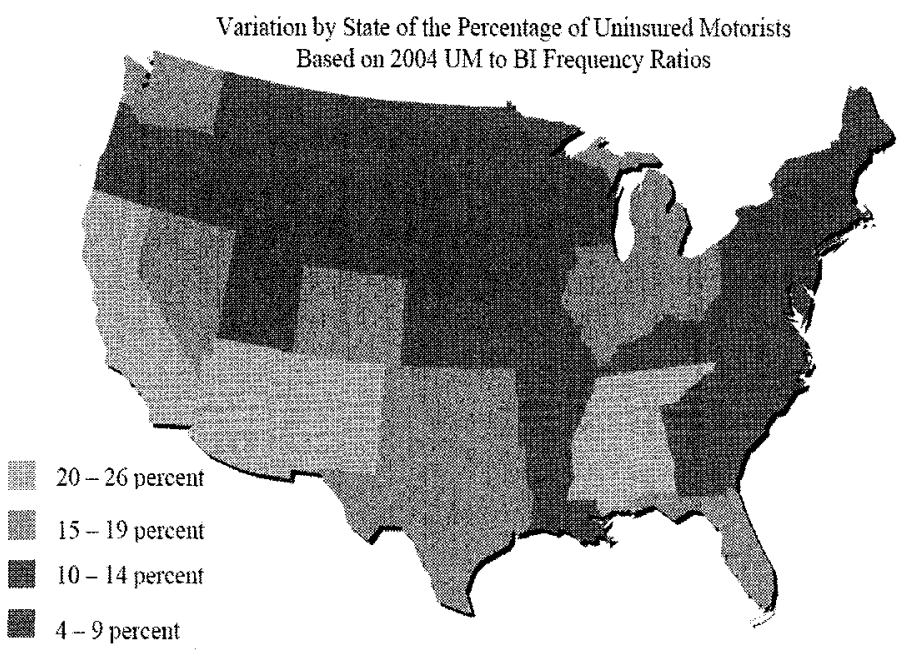

40. MassachusetTs Health Care Reform, supra note 14, at 2.

41. See id. (stating that during the first year of the program the penalty will be loss of the personal exemption from state income tax, and in subsequent years the penalty is $50 \%$ of the cost of a standard insurance policy).

42. The statement in the text is true across the entire population, but age variation in pricing complicates matters. Health insurance for young adults is cheap (or would be in the absence of community rating), while auto insurance for the young is quite expensive.

43. News Release, Insurance Research Council, IRC Estimates More Than 14 Percent of Drivers Are Uninsured, available at http://ircweb.org/news/20060628.pdf [hereinafter IRC].

44. Id.

45. IRC, supra note 43 , at 2 . 
If an individual mandate doesn't work with auto insurance, why should we expect it to work with health insurance?

\section{V. "THE UGLY"}

\section{A. Out-year Costs? What Out-year Costs?}

The Massachusetts health plan is projected to cost approximately $\$ 1.4$ billion per year over three years, and no amount was budgeted for years 2010 and beyond. ${ }^{46}$ Massachusetts plans to raise the $\$ 1.4$ billion with a limited amount of new funding (derived from general revenue and employer contributions), but most of the money will come from diverting existing funding (federal Medicaid payments previously earmarked for safety net providers and payments by employers to the state uncompensated care pool). ${ }^{47}$ Have you ever heard of a government program that required $\$ 1.4$ billion per year for the first three years, and no additional funding thereafter to offer the same benefits-particularly when spending is expected to exceed revenue in its third year by almost $\$ 170$ million? ${ }^{48}$ Me neither.

\section{B. Let's Regulate!}

A big part of the reason many people do not have health insurance is that it is too expensive. ${ }^{49} \mathrm{~A}$ big part of the reason why health insurance is too expensive is because of well-meaning regulation, whether in the form of benefit mandates, guaranteed issue, community rating, or restrictions on offering "last year's medicine at last year's prices." Although Massachusetts eliminated some regulations that made the

46. McDonough et al., supra note 7, at w425 ex. 2; see also MASSACHUSETTS HEALTH CARE REFORM, supra note 14, at 2 ("The state anticipates that no additional funding will be needed beyond three years.").

47. Massachusetts Health CARe Reform, supra note 14, at 2.

48. McDonough et al., supra note 7, at w425 ex. 2.

49. See Hyman, supra note 30 , at $272-73$ ("[T]he reason we have so many uninsured is that we have priced the minimum level of coverage above the ability and willingness of Americans to pay ...."); see also Hyman \& Hall, supra note 23, at 26 ("Commentators wax poetic about the social role of health insurance, and treat the decision to offer and purchase such coverage in morally weighted terms. However, the evidence is fairly clear that potential subscribers approach coverage decisions in traditional economic terms. When faced with a choice of health care coverage, price is the key driver of the decision-making process, and a significant number of individuals who have access to coverage through their employer decline it on the grounds it is too expensive.").

50. Hyman, supra note 30 , at 275 ; see also id. at 271 ("[G]overnment action generally favors the concentrated interests of incumbent providers and hurts, rather than helps, consumers.”). 
individual and small group markets more expensive than they needed to be, the Connector still retains much of the command-and-control approach to health insurance that helped cause the problem in the first place - and the requirement that privately purchased insurance meet state-dictated standards to be "creditable" under the Massachusetts health plan compounds the problem. Consider a small, but telling, example. All policies offered through the Connector have to cover treatment for infertility, including in vitro fertilization (IVF) ${ }^{51}$ It is hard to conceive (pun intended) of the circumstances where that decision makes any sense whatsoever, apart from its appeal to the naked self-interest of those providing such services. ${ }^{52}$

When regulators internalize the costs of their decisions, they suddenly become more sensitive to the associated trade-offs. ${ }^{53}$ Even if

51. Transcript of Health Care Reform: The Massachusetts Model, supra note 7.

52. The process of mandating benefits at the federal and state levels has been dogged by this problem. See generally Hyman, supra note 30, at 265 ("[T] interests of providers and high-income consumers of health-care services."); David A. Hyman, Regulating Managed Care: What's Wrong With A Patient Bill of Rights, 73 S. CAL. L. REV. 221, 237-53 (2000) (discussing the slanted evidence legislators rely on to make their decisions and how their preferences can be easily swayed).

53. My favorite example is the famous takings case, Lucas v. South Carolina Coastal Council, 505 U.S. 1003 (1992). South Carolina passed a law which prohibited building on certain beachfront property on grounds of public safety. $I d$. at 1008 . The Supreme Court held this law to constitute a taking, absent a common law nuisance. $I d$. at 1031. After the Supreme Court's opinion, the South Carolina Coastal Council (SCCC) settled the case by purchasing the two lots in question for $\$ 425,000$ per lot plus interest and legal fees. See Gideon Kanner, Not with a Bang, but a Giggle: The Settlement of the Lucas Case, in TAKINGS: LAND DEVELOPMENT CONDITIONS AND REgUlATORY TAKINGS AFTER DOLAN AND LUCAS 308, 309 (David L. Callies ed., 1996). During the years of litigation, the SCCC had consistently claimed that there was a "threat to life and property" if the beachfront lots were built upon. Id.

Once it actually owned the lots, the SCCC underwent a "neck-snapping, intellectual aboutface," and concluded that it was "reasonable and prudent"" for houses to be built on the lots. Id. When the lots were offered for sale, a $\$ 315,000$ bid was made on one of the lots with the understanding that it would remain unimproved. Id. at 310 . The SCCC refused this bid, and ultimately sold both lots to a developer for $\$ 392,500$ per lot. Id. Thus, once it owned the property, the SCCC was unwilling to take a loss of $\$ 77,000$ to keep one lot unimproved, $i d$, but it was perfectly happy in its role as regulator to impose a cost of more than ten times that amount on $\mathrm{Mr}$. Lucas to keep both lots vacant.

In the health care setting, the drive-through delivery mandate demonstrates a similar pattern Prior to the passage of the Newborns' and Mothers' Protection Act, twenty-nine states had enacted prohibitions on rapid postpartum discharges. David A. Hyman, Drive-Through Deliveries: Is "Consumer Protection" Just What the Doctor Ordered?, 78 N.C. L. REV. 5, 24 (1999). Eighteen of the states excluded Medicaid from the scope of these statutes. Id. at 26. Nineteen excluded state employees. Id. The only thing these two populations have in common is that states bear a significant percentage of the cost of providing health care coverage to both of them. "Thus, most state legislatures displayed concern for the plight of women and infants 'victimized' by drivethrough deliveries only as long as state governments did not have to foot the bill to fix the problem." Id. For further discussion of the politicization of the abolishment of "drive-through" deliveries, see David A. Hyman, What Lessons Should We Learn From Drive-Through Deliveries?, 107 
regulators do not internalize their costs, concern about feasibility and public acceptability can force regulators to become more modest about both their means and ends. For example, the Connector board initially proposed to restrict policies with high deductibles and out-of-pocket limits, but it is currently reconsidering that position because the monthly premiums proposed by insurers for such coverage is much higher than expected-let alone compared to the premium that is politically feasible. $^{54}$

Regulation may be necessary to deal with some specific forms of market failure, but it should be enacted only after due consideration of comparative institutional imperfection and the nirvana fallacy. ${ }^{55}$ Massachusetts appears to be incapable of learning this lesson.

Finally, the regulations that were adopted do nothing about the cost of health care in Massachusetts - and in the long run, that problem will swamp any reform proposal, including the Massachusetts health plan.

PEDIATRICS 406, 406-07 (2001).

54. See Alice Dembner, Universal Plan Can Cost Under \$300, Insurers Say Monthly Price is Closer to Goal, BOSTON GLOBE, Feb. 5, 2007, at A1 ("The connector's policy committee decided in November that the minimum plans should provide comprehensive coverage, including prescription drugs, and hired an actuary to model a minimal plan. It came back with a $\$ 260$ average premium and a fairly high deductible, which applied to hospital benefits. But when the board sought bids from insurers, many came in substantially higher. A summary prepared by board staff showed monthly premiums ranging from $\$ 250$ for a 28 -year-old to $\$ 500$ for a 56-year-old, which one board member averaged to about $\$ 380$."). The result is that the Connector Board is now reconsidering its requirements. Id:; see also Alice Dembner, Sticker Shock for State Health Care Plan, Average Premium of $\$ 380$ Outlined, Boston GloBE, Jan. 20, 2007, at Al ("Advocates for the uninsured were stunned at the price, considerably higher than the $\$ 200$ estimated by Mitt Romney when he was governor and first proposed universal coverage. A spokesman for insurers said the requirements were too prescriptive and could undermine the goal of universal coverage.").

55. See Richard A. EPSTEIN, Simple Rules fOR A COMPlex World 32 (1995) ("First-best solutions are rarely, if ever, possible; thus the beginning of wisdom is to seek rules that minimize the level of imperfections, not to pretend that these do not exist. No contract, no association is ever bullet proof: no matter what rights, duties, institutions, and remedies are chosen, in some circumstances they will be found wanting. Bad outcomes are therefore consistent with good institutions, and we cannot discredit these institutions with carefully selected illustrations of their failures. Counterexamples may be brought to bear against any set of human institutions. The social question, however, is concerned with the extent of the fall from grace. The fact of the fall should be taken as a necessary truth, not a shocking revelation. Perfection is obtainable in the world of mathematics, not in the world of human institutions."); Harold Demsetz, Information and Efficiency: Another Viewpoint, 12 J.L. \& ECON. 1, 1 (1969) ("The view that now pervades much public policy economics implicitly presents the relevant choice as between an ideal norm and an existing 'imperfect' institutional arrangement. This nirvana approach differs considerably from a comparative institution approach in which the relevant choice is between alternative real institutional arrangements."). 


\section{CONCLUSION}

The Massachusetts health plan is a bipartisan success storyalthough as Senator Ted Kennedy wryly noted at the signing ceremony, "when you come to a celebration of a signing and Mitt Romney and Ted Kennedy and the Heritage Foundation are all together, it's clear one of us didn't read the bill." 56 How did it come about that Massachusetts was where these reforms happened?

Massachusetts began with three important advantages in addressing the problems of the uninsured. Compared to the other forty-nine states, Massachusetts is richer, with a smaller percentage of its population uninsured, and it was already receiving $\$ 385$ million per year in "extra" Medicaid funding. ${ }^{57}$ Massachusetts also labors under several disadvantages in addressing the problems of the uninsured, including the fact that, compared to forty-eight of the other forty-nine states, the health care delivery system in its principal city is overwhelmingly based on an expensive infrastructure of teaching hospitals and academic medical centers. The Massachusetts health plan represents an attempt to reconcile these inconsistencies and provide affordable private-sector coverage to those currently without health insurance-an effort spurred by the Presidential ambitions of its then-governor, and the imminent loss of its "extra" Medicaid funding. . $^{8}$

Will the Massachusetts health plan work? Only time will tell, but there is enough "bad" and "ugly" in the mix to raise serious concernsparticularly when the desire to overregulate the health insurance market appears to be hard-wired into the DNA of Massachusetts' health policy.

Where, then, should we go from here? Regulatory federalism offers one intriguing possibility that builds on (but turbo-charges) the model of the laboratory of the states. Eliminating state-specific monopolies for the

56. Transcript of Health Care Reform: The Massachusetts Model, supra note 7

57. See McDonough et al., supra note 7, at w430 ("Massachusetts entered this process with an uninsurance rate lower than most states ...."); see also Christopher Rowland, Mass. Health Plan Seems Unlikely to be US Model: Demographics in State's Favor, Boston GloBE, Apr. 14, 2006, at Al (noting Massachusetts has fewer uninsured residents compared to the rest of the nation).

58. See Haislmaier, supra note 8 ("The Romney administration seized the opportunity presented by the impending expiration of the state's Medicaid waiver to tackle covering uninsured individuals who are ineligible for Medicaid. That waiver currently pumps $\$ 385$ million a year in federal Medicaid money into the state's $\$ 1$ billion per year uncompensated care pool ... Federal Medicaid officials told Massachusetts that they would not approve a waiver extension absent a state plan to achieve better results with the money."); see also Belluck, supra note 1 (noting that Massachusetts was "motivated in part by a threat by the federal government to eliminate $\$ 385$ million in federal Medicaid money unless the state reduced the number of uninsured people"). 
regulation of health insurance and moving toward a corporate law model would transform the market. Employers and insurers would be required to subject themselves to the laws and regulations of a single state, but they would be allowed to select the state. As with corporate charters, this system would create a market for regulatory oversight, and would allow employers and insurers to select the regulatory regime that functions most efficiently and cost-effectively matches the needs and preferences of their risk pool(s). The ability of employers and insurers to exit from the state's regulatory oversight (taking their premium taxes with them) would temper opportunistic behavior by legislators and regulators. A race to the bottom would be unlikely because the state's residents would be the first to be affected.

In Groundhog Day, Bill Murray is forced to live the same day over and over again. ${ }^{59}$ The debate over the uninsured has had a similar feel for the past several decades. ${ }^{60}$ If nothing else, Massachusetts has changed the state of play in that debate-and, as Bill Murray notes at the very end of Groundhog Day, "anything different is good.",61

59. Groundhog DAY (Columbia Pictures Corp. 1993).

60. See BIG (20th Century Fox 1988) ("All the same people having all the same discussion. It's like they cloned some party in 1983 and kept spinning it out again and again and again.").

61. GROUNDHOG DAY, supra note 59. 
$* * *$ 